\title{
ГОТОВНІСТЬ МЕДИЧНИХ СЕСТЕР ЗАГАЛЬНОЇ ПРАКТИКИ ДО САМОСТІЙНОГО ВИКОНАННЯ ІННОВАЦІЙНИХ СЕСТРИНСЬКИХ КОМПЕТЕНЦІЙ
}

\author{
Я. В. Коморнаํㅛ І. Я. Криницька ${ }^{2}$, Н. В. Гецько², М. І. Марущак² \\ ${ }^{1}$ Комунальне некомерційне підприємство Броварської міської ради «Броварський \\ міський центр первинної медико-санітарної допомоги” \\ ${ }^{2}$ Тернопільський національний медичний університет \\ імені І. Я. Горбачевського МОЗ Украӥни
}

У статті йдеться про готовність медичних сестер загальної практики до самостійного виконання медичних компетенцій на рівні центру первинної медико-санітарної допомоги.

\section{READINESS OF GENERAL PRACTICE NURSES FOR INDEPENDENT PERFORMANCE OF INNOVATIVE NURSING COMPETENCES}

\author{
Ya. V. Komorna ${ }^{1}$, I. Ya. Krynytska², N. V. Hetsko², M. I. Marushchak ${ }^{2}$ \\ ${ }^{1}$ Municipal non-profit enterprise of Brovary City Council "Brovary City Center \\ of Primary Health Care" \\ ${ }^{2}$ I. Horbachevsky Ternopil National Medical University
}

\begin{abstract}
The article is devoted to determining the readiness of general practice nurses to independently performing of medical competencies at the center of primary health care.
\end{abstract}

Вступ. Медична сестра є важливим важелем, який формує здоров'я населення, впливає на перебіг захворювань, відновлює стан здоров'я людини, пропагує здоровий спосіб життя, долучається до розробки заходів, спрямованих на фактори, що можуть негативно позначитись на здоров'ї, забезпечивши тим самим попередження і зниження захворюваності, поліпшення спадковості, гармонійний розвиток населення України [1-4]. Особливо це стосується роботи середнього медичного персоналу первинної ланки охорони здоров'я. Медична сестра загальної практики разом з хворим і з його родичами, а не лише з лікарем, планує заходи, які необхідно провести для досягнення конкретно поставленої мети; вона допомагає пацієнту долати всі труднощі та перешкоди на шляху до одужання, залучаючи до цього процесу всю родину, формуючи їх ставлення до власного здоров'я та профілактики захворювань [5-9].

Однією з основних функцій соціально-орієнтованих медичних сестер є самостійний сестринський прийом пацієнтів, у ході якого збирають первинний анамнез (скарги, рівень артеріального тиску, температура тіла й інше), антропометричні дані пацієнта, складають соціальний паспорт сім'ї, визначають критерії неблагополуччя в сім'ї. Будучи координатором маршруту пацієнта, медична сестра приймає рішення про подальший рух пацієнта, а сама починає працювати з наступним пацієнтом. Тому метою нашої роботи було оцінити готовність середніх медичних працівників загальної практики до самостійного виконання медичних компетенцій на рівні центру первинної медико-санітарної допомоги.

Основна частина. Для визначення готовності середніх медичних працівників до самостійного виконання медичних компетенцій проведено дослідження шляхом анкетування 30 медичних сестер загальної практики Комунального некомерційного підприємства Броварської міської ради «Броварський міський центр первинної медико-санітарної допомоги» (далі - Центр), яке створено рішенням Броварської міської ради Київської області від 07.07.2013 р. № 972-36-06 і розпочало свою роботу з 01.01.2014 р. 
Основною метою діяльності Центру є забезпечення організації кваліфікованої первинної лікувальнопрофілактичної допомоги населенню м. Бровари, проведення комплексу профілактичних заходів з попередження і зниження захворюваності, інвалідності та смертності, раннього виявлення захворювань, надання прикріпленому за сімейно-територіальним принципом населенню кваліфікованої первинної лікувально-профілактичної допомоги, здійснення його диспансеризації та моніторингу за станом здоров'я, дотримання прав і обов'язків пацієнтів.
Основними параметрами дослідження були готовність медичних сестер загальної практики до виконання таких функціональних обов'язків, як: патронаж здорових дітей до 1 року вдома, активний патронаж диспансерних хворих із хронічними захворюваннями вдома, долікарське обстеження пацієнта, самостійний прийом щодо медико-соціальних питань, виписування рецептів хворим, які перебувають на диспансерному обліку, проведення бесід з населенням із питань пропаганди і формування здорового способу життя, імунопрофілактика, проведення скринінгу, навчання пацієнтів у школах здоров'я (табл. 1).

Таблиця 1. Оцінка готовності медичних сестер загальної практики до самостійного виконання медичних компетенцій

\begin{tabular}{|c|c|c|}
\hline \multirow{2}{*}{ Функція } & \multicolumn{2}{|c|}{ Готовність виконання } \\
\hline & так & $\mathrm{Hi}$ \\
\hline Патронаж здорових дітей до 1 року вдома & $23,3 \%(n=7)$ & $76,7 \%(n=23)$ \\
\hline $\begin{array}{l}\text { Активний патронаж хворих із хронічними захворюван- } \\
\text { нями вдома }\end{array}$ & $50,0 \%(n=15)$ & $50,0 \%(n=15)$ \\
\hline Самостійний прийом щодо медико-соціальних питань & $66,7 \%(n=20)$ & $33,3 \%(n=10)$ \\
\hline Долікарське обстеження пацієнта & $56,7 \%(n=17)$ & $43,3 \%(n=13)$ \\
\hline Виписування рецептів хворим & $90,0 \%(n=27)$ & $10,0 \%(n=3)$ \\
\hline $\begin{array}{l}\text { Проведення бесід з населенням із питань пропаганди і } \\
\text { формування здорового способу життя }\end{array}$ & $93,3 \%(n=28)$ & $6,7 \%(n=2)$ \\
\hline Імунопрофілактика & $30,0 \%(n=9)$ & $70,0 \%(n=21)$ \\
\hline Проведення скринінгу загального (анкетування) & $76,7 \%(n=23)$ & $23,3 \%(n=7)$ \\
\hline $\begin{array}{l}\text { Проведення скринінгу цільового (вимірювання арте- } \\
\text { ріального тиску, визначення експрес-методом глюко- } \\
\text { зи, холестеролу, протеїну, білірубіну та ін., офтальмо- } \\
\text { тонометрія, спірометрія, ЕКГ) }\end{array}$ & $93,3 \%(n=28)$ & $6,7 \%(n=2)$ \\
\hline Навчання пацієнтів у школах здоров'я & $86,7 \%(n=26)$ & $13,3 \%(n=4)$ \\
\hline
\end{tabular}

За результатами опитування медичних сестер загальної практики, встановлено їх найвищу готовність до виконання таких функціональних обов'язків, як: виписування рецептів хворим, проведення бесід з населенням із питань пропаганди і формування здорового способу життя, навчання пацієнтів у школах здоров'я (рис. 1).

$93,3 \%$
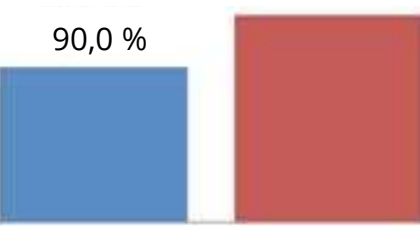

виписування рецептів хворим

$$
\begin{gathered}
\text { проведення бесід } \\
\text { з населенням із } \\
\text { питань пропаганди і } \\
\text { формування здорового } \\
\text { способу життя }
\end{gathered}
$$

Найнижчу готовність до виконання функціональних обов'язків встановлено для: патронажу здорових дітей до 1 року вдома, імунопрофілактики, долікарського обстеження пацієнта, активного патронажу хворих із хронічними захворюваннями вдома (рис. 2).

\section{PUс. 1. Найвища готовність виконання функціональних обов'язків медичними сестрами загальної} практики. 


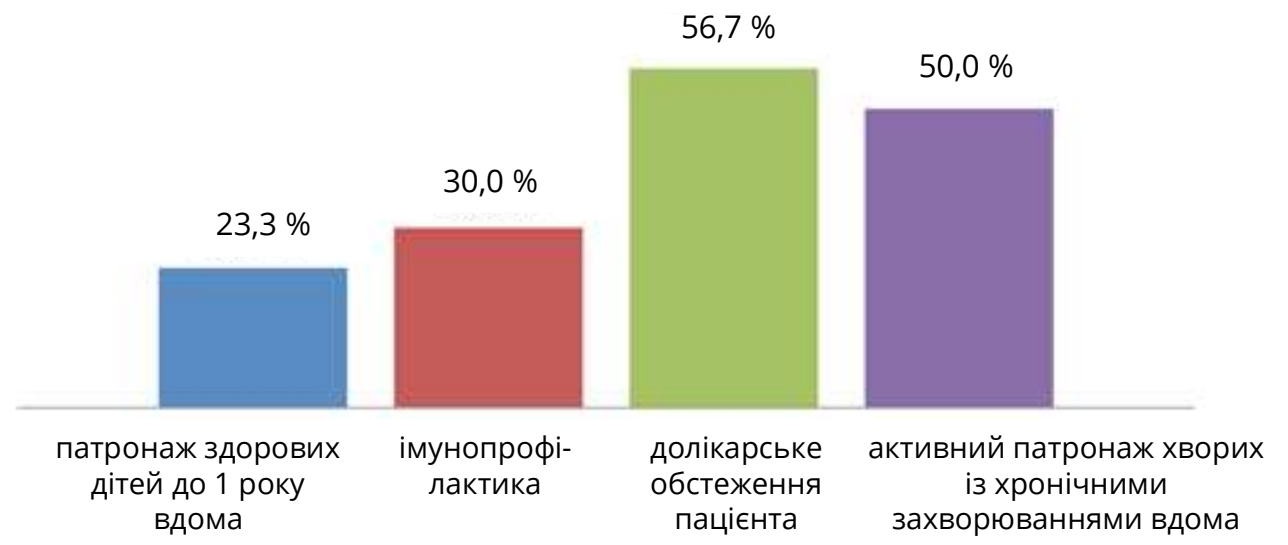

Puc. 2. Найнижча готовність виконання функціональних обов'язків медичними сестрами загальної практики.

Висновки. Згідно з даними нашого дослідження, середні медичні працівники, які беруть участь в традиційному вигляді прийому, не зовсім готові до самостійного виконання інноваційних сестринських компетенцій. Ймовірно, це пов'язано з відсутністю стандартів із надання самостійної сестринської допо-

\section{СПИСОК ЛІТЕРАТУРИ}

1. Кабанцова А. В. Сучасний стан медсестринського процесу (огляд літератури) / А. В. Кабанцова // Медсестринство. - 2012. - № 3. - С. 35-38.

2. Юристовська Н. Напрямки державного забезпечення рівноправності у доступі до медичних послуг сільського населення у процесі реформування системи охорони здоров'я / Н. Юристовська // Ефективність державного управління. - 2017. - Вип. 4 (53). - С. 121-129.

3. Воропаева Л. А. Роль медсестры в решении актуальных проблем клинической практики / Л. А. Воропаева, А. В. Голенков, А. В. Оверин // Сестринское дело. - 2012. - № 8. - С. 12-13.

4. Чернявська Л. І. Стан здоров'я студентів, проблеми та шляхи їх вирішення / Л. І. Чернявська, І. Я. Криницька, О. П. Мялюк // Медсестринство. - 2017. - № 1. - С. 24-27.

5. Медсестринство в сімейній медицині / Є. Х. Заремба, Г. Ф. Левченко, В. М. Михальчук та ін. ; за ред. Є. Х. Заремби. - К. : Здоров'я, 2001. - 312 с. моги, недостатньою законодавчою базою практики самостійного прийому медичних сестер, консерватизмом поглядів медичних працівників на необхідність зміни своєї діяльності. Крім того, важливим фактором $\epsilon$ недостатня укомплектованість штату середнім медичним персоналом.

6. Шарлович 3. П. Науковий підхід до аналізу процесу підготовки сімейних медсестер в системі фахової та неперервної медичної освіти / 3. П. Шарлович // Теорія і практика підготовки майбутніх учителів до педагогічної дії : зб. матеріалів конференції. - Житомир : Вид-во ждУ ім. Івана Франка, 2011. - С. 230-236.

7. Абзалова Р. А. Потенциальные возможности специалистов сестринского дела в оказании первичной медико-санитарной помощи / Р. А. Абзалова, А. А. Искакова // Психиатрия, психотерапия и наркология. Специальный выпуск. - 2014. - № 2-3 (39). - С. 7-8.

8. Task shifting of antiretroviral treatment from doctors to primary-care nurses in South Africa (STRETCH): a pragmatic, parallel, cluster randomised trial / L. Fairall, M. O. Bachmann, C. Lombard [et al.] // Lancet. - 2012. - Vol. 380. - P. 889-898.

9. Primary care practice composition in 34 countries / P. Groenewegen, S. Heinemann, S. Gress, W. Schafer // Health Policy. - 2015. - Vol. 119 (12). - P. 1576-1583. 